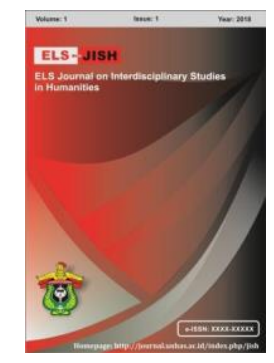

ELS-JISH

ELS Journal on Interdisciplinary Studies on Humanities

Volume 3 Issue 2, 2020

ISSN (print) : 2621-0843

ISSN (online) : 2621-0835

Homepage : http://journal.unhas.ac.id/index.php/jish

\title{
Women's Roles in Puritan Society as reflected in Nathaniel Hawthorne's The Scarlett Letter
}

\author{
Rina Marliana ${ }^{1}$, Nihla Afdaliah ${ }^{2}$ Rismawati $^{3}$ \\ ${ }^{1} \underline{\text { rinamarlianass@gmail.com }}$
}

\begin{abstract}
Literature serves as a reflection or a mirror for society. Nathaniel Hawthorne's Scarlett Letter is one of the literary works that can reflect the social problems or anomalies that puritan society has in America. This work was a qualitative description. Both data was gathered through library research and analyzed by Swingewood (1972), which showed that there are three classifications of the literary sociology. In this case, the researchers mainly concentrated on classifying sociology as a mirror of society's age or image. The results of this research show that the key role of women in puritanical society is to teach their children the scriptures.
\end{abstract}

Keywords: Puritan, Women Roles, Mirror of Society, Scripture

How to cite: Marliana, R., Afdaliah, N., \& Rismawati. (2020). Women's Roles in Puritan Society as reflected in Nathaniel Hawthorne's The Scarlett Letter. ELS Journal on Interdisciplinary

Studies in Humanities, 3(2), 265-270. DOI: 10.34050/els-jish.v3i2.10046

\section{Introduction}

Literature in various genres provides social messages that ideally carry equality and peace in countries hindered by different ethnic groups (Rahman \& Weda, 2018). Literary work is a result of author's expression on what he is seeing in the social life and then he will be expressed by using language as one of his communication tools (Halim: 2003). It can be a life experience, an imagination, a feeling, or an idea of the author; which is poured through language then is offered to public as a description of social life. Marliana et al ( 2018) have stated that literature generally records social conditions, social phenomena, and even social movement. As a reflection of reality, it is difficult to distinguish literature from society. This reveals not only a view of human life, but also the problems of a given society.

Literature can be considered the origins of social and historical events or records of social phenomena. Literature plays a vital role in educating and recognizing social problems such as the natural, urban, religious, fictional and moral aspects of a particular society. Literature itself is not the same as other social records, though, because it is the synthesis of fact and imagination that is useful to attach aspects and give meaning to truth.

${ }^{12}$ Sekolah Tinggi Agama Islam Negeri Majene, Indonesia 
Laurenson and Swingewood (1972) also notes that literary sociology has three perspectives. First, literary research is considered a representation of age or class, secondly, literary research is considered the sociology of the author; lastly, it is study which considers literary work as a manifestation of historical events and of the social state of society.

Yuliati (2015) claimed that the term puritan was first used by those who promoted more cleanliness of worship and theology in the 1560s. Puritans have claimed that Henretta et al (2002) assumed that all people had fixed destinies set by God in their conception. In order to be "saved" heaven, you will live your lives according to the will of God and carry out your dream for them in a certain way.

Gender roles are a collection of social and behavioral standards generally accepted as socially acceptable to individuals of a particular gender within a particular community. Gender role interpretation involves behaviors, behavior and personality characteristics linked to a specific sex within that society. Puritans society has a rule that will manage the relation among the puritans society. The rule of puritans is based on the Bible. John von Rohr in Campbell (2010) stated that the roles of women in a Puritan society include offering the home a spiritual sky, children, acting as sisters for other women working in the workplace, teaching children to read the Bible and write in their households, care and health care for children and spouses, attending worship services, but failing to express themselves or pray, and not attending the services.

The role of women in Puritan communities in the 16th or 17th centuries was to increase the rights of their children and to teach them certain moral values. The women must teach their children about their commitment to God and the religious myths and teachings. They 'd eat, clean and knit, Puritan women were expected to do all these things, so if they didn't do as they could, the society's would kick them out. Puritan women were extremely loyal to their husbands and very dedicated to their duties in their households.

The Scarlet Letter is a book written by Nathaniel Hawthorne full of social facets. The social aspects such as religion, community and the role of women in the puritanical society in this novel. In Boston, Massachusetts, the Scarlet Letter of Nathaniel Hawthorne was written in the 17th century in the sense of the Puritan settlement. The entire plot of The Scarlet Letter involves conflicts between the victim or the main character and society in which the role of society in maintaining its members is portrayed. The novel shows us secret guilt and culpability because of Puritan bigotry. One of the reasons is the secret sin issue of Reverend Arthur Dimmesdale and Hester Prynne, the heroine of the book. Arthur Dimmesdale is a puritan society in Boston that commits adultery with Hester Prynne, a lovely young woman. Adultery was considered at that time a great $\sin$ which seriously punishes those who do so. Interestingly, Arthur Dimmesdale was lauded by his congregation for his excellent sermon and conduct as Hester was subjected to some embarrassed punishment.

Numerous researchers have analyzed from many different perspectives of "The Scarlet Letter" book. Therefore, in order to deepen the analysis and use it both as a reference and comparison to this investigation, it is important to 
examine this study to increase knowledge of other related research. An duplication in work must also be avoided. Arif (1998) analyzes Hester Prynne, the main character of the Scarlet letter, which starts with Hawthorne's presumption of a fallacy in presenting practical and scientific problems without a rational solution. In order to describe the main character, Hester, the scientist uses systemic, sociological and feminist approaches. Nurin Antasari (2010), analyzed Arthur Dimmesdale's hypocrisy as a puritan clergyman in Nathaniel Hawthorne's The Scarlet Letter which is focus on the character Arthur and his hypocrisy, this analysis used a sociological approach. In this paper, the researcher find out the Women's roles in Puritan society, which identifies the women's role by using sociological literature approach by Laurenson and Swingewood that focused on literature as manifestation of historical event and socio cultural condition. Thus, the researcher explores the new perspective which is different from the previous research.

\section{Method}

\subsection{Research Design}

The study design is a systematic effort by the researcher to collect his / her research data (Arikunto: 2002). This is a qualitative method of description. Throughout descriptive analysis, according to Fitria (2020) the question is stated explicitly based on the most precise facts, and the focus on the theory used is explained and represented. In order to complete this study, the researcher uses Laurenson and Swingenwood's sociology of literature approach. The study focuses on the role of women in puritanical society as reflected in the Scarlett Letter Novel.

\subsection{Source of Data}

The researchers used the data from Nathaniel Hawthorne's The Scarlett Letter. The researchers took Scarlett Letter Novel from various books, posts, journals and websites and published it in 1994 as primary and secondary data. With these secondary data, the researcher collects and uses the data as relevant to the subject.

\subsection{Procedures}

The researcher gathered the data from the novel itself, the literary context, and other scientific publications linked to the study. Secondly, the researchers have used the approach of library study, which helps them to gather many sources relevant to study, such as papers, textbooks, journals, both in print and in electronic form, to provide information on detail related to the topic of this research. The research deals with social and cultural studies in the puritan society in particular. It demonstrates the role of literature as a way of expressing or reflecting social life and issues.

\subsection{Data Analysis}

In this research, the writer analyzed the data by using "sociological approach". The sociological approach is the approach to analyze the intrinsic structure of the novel. The data that is collected and analyzed to find out the objective of the research. The researcher analyzed the data by following several 
steps. First step is Identification that is to identify all of the texts in The Scarlet Letter novel that shows the Puritanism aspects such as beliefs, culture and women's role in Puritan society. Second step is reduction and categorization, that is select and distinguish the data based on its types. The last step is display, which is making a relation between one data to another data to get the relevant relation of the whole data

\section{Findings and Discussion}

This novel, The Scarlet letter by Nathaniel Hawthorne can be a social document that shown the social phenomena in Puritan society. There are many a rules of puritan society in this novel. The writer only focused with the women's roles in puritan society particularly the roles of teaching the holy bible or scripture to the children. The women roles in puritan society are teach children about the Bible and their reading and writing in the home (John Von Rohr, 1986: 58). The researcher find out the women's role in Puritan society in The Scarlet Letter novel to teach the children about bible or scripture is very crucial.

"The discipline of the family in those days was of a far more rigid kind than now. The frown, the harsh rebuke, the frequent application of th e rod, enjoined by Scriptural authority, were used, not merely in the way of punishment for actual offences, but as a wholesome regimen for the growth and promotion of all childish virtues. Hester Prynne, nevertheless, the loving mother of this one child, ran little risk of erring on the side of undue severity." (Hawthorne, 1994: 136)

"Say thou, the mother of the boy! Was it not for thy little one's temporal and eternal protection, thinkest thou, that she should be taken out of thy care, and clothed with sobriety, and strictly regulated, and instructed in the truths of heaven and earth? How would you do for a kid of this kind? (Hawthorne, 1994: 165)

The data above show the mother's duty is follow the discipline and the guidance in the Scriptural authority or the holy bible of puritan society. The data shows Hester Prynne, as mother, even she loves and cares with her daughter Pearl, she also punishes Pearl if Pearl does mistakes and disobey the role in the scripture. The data above, explained clearly about the women's responsibility in teaching their child about the bible. They are believed that the scripture is the instructed the truths of heaven and earth. All the puritans should know the role in the scripture started when they were 3 years old. That is the Mother's job to teach their child about the Scripture or the bible not the job of the father.

These entire things must be done by the mother or the puritan women, the mother will be judge as irresponsible mother if their children cannot follow the rules in the scripture. Giving punishment to the children is a common thing in Puritan society. They are believe it could make their children to be more discipline.

"'This is awful!' cried the Governor, slowly recovering from the astonishment into which Pearl's response had thrown him. 'Here is a child of three years old, and she cannot tell who made her! Without question, 
she is equally in the dark as to her soul, its present depravity, and future destiny! "(Hawthorne, 1994 : 168)

One of the failures of the parent in Puritan society as reflected in this novel is when the children don't know their creator. In the data above, the governor said word 'awful' as he expressed his emotion. If the children do not know their creator, it means the parents are irresponsible parent that cannot educate their children. The puritan believes in the scripture or holy bible, where all the rules of their life are written there. They should study about it since they were 3 years old. If the children in the community does not have a comprehension about the scripture, that is the parent responsibility.

Another data that supported the previous data is:

"My poor woman,' said the not unkind old minister, 'the child shall be well cared for-far better than thou canst do for it."' (Hawthorne, 1994: 168)

The phrase "My poor woman" that attached to Hester as a mother because they Puritan society assume that she is a bad mother not a good mother. The data above is the statement of the clergymen in Puritan society. The clergymen will take Hester's daughter, Pearl from Hester Prynne, because they believed that Hester can't do their responsible as a mother to teach Pearl about truths of heaven and earth or the instruction and rule in Holy bible. That is proved by sentence "the child shall be well cared for-far better than thou canst do for it".

The way Puritan society in the New England in mothering their child is should be based on the scripture, The Scarlet Letter shows this phenomenon to the reader as the historical document as well as the reflection of the society.

\section{Conclusion}

There are some women's roles in Puritan society, the researcher only focus on the women roles to teach the children the Scripture or the holy bible. The data in this research show that how strict the puritan rules in their society, all the rules are taken from the scripture. The puritan women should be a good mother to their children, one of the criteria of good mother is they should teach their children about the scripture and the holy bible as the instruction and the truth of heaven and earth.

\section{References}

Antasari, N. (2010). Arthur Dimmesdale's Hypocrisy as a Puritan Clergyman in Nathaniel Hawthorne's The Scarlet Letter (sociological approach). Unpublished thesis. Surakarta: USM

Arif, A. (1998). The Misled Feminist in Nathaniel Hawthorne's The Scarlet Letter. Unpublished thesis. Surakarta. Surakarta: UNS.

Arikunto, S. (2002). Prosedur Penelitian, Suatu Pendekatan Praktek. Jakarta : PT Rineka Cipta

Campbell, D. M. (2010). Puritanism in New England "Literary Movement. Dept. of English, Washington State University. 
Eagleton, T. (2001). Literary Theory an Introduction $2^{\text {nd }}$ ed.. Great Britain : Minesota.

Fitria,T. N (2020). Translation Technique of English to Indonesian Subtitle in "Crazy Rich Asian" Movie. ELS Journal on Interdisciplinary Studies on Humanities. 3(1), 51-65

Halim, A. (2003). Introduction to Literature. Makassar : UNM Press.

Hawthorne, N. (1994). The Scarlet Letter. New York: Dover Publication Inc.

Henretta, J., et al. (2002). "Puritan New England." In America: A Concise History. Vol. 1, $2^{\text {nd }}$ ed. Boston: Bedford/St. Martin's.

Laurenson D. \& Swingewood A. (1972). The Sociology of Literature. London : Granada Publishing Limited

Marliana R., et al. (2018) Convicts Life in James Tucker's The Adventure of Ralph Rasleigh. ELS Journal on Interdisciplinary Studies on Humanities. 1(1). 76-82

Rahman, F., \& Weda, S. (2018). Students' perceptions in appreciating English literary works through critical comment: A case study at Hasanuddin University and Universitas Negeri Makassar. Asian EFL Journal, 20(3), 149-172.

Wellek, R. and Austin, W. (1956). Theory of Literature. New York: Harcourt, Brace \& company. 